\title{
FRIDA MEYER \\ SOCIABILIDADE FEMININA \\ NA PORTO ALEGRE DOS ANOS 1920
}

Milena Ribeiro Martins 
RESUMO Este artigo apresenta o romance Frida Meyer (1924), de Vivaldo Coaracy, da perspectiva da História do Livro, propondo vínculos entre o texto literário e sua materialidade gráfica. Em seguida, documenta seu processo de edição, traz dados para o estudo de sua circulação e discute sua primeira recepção crítica. Por meio da análise de elementos centrais da trama romanesca, este texto procura ainda suscitar a leitura do romance de Vivaldo Coaracy, atribuindo importância à representação da vida íntima e social das mulheres, do ambiente urbano de Porto Alegre e do contexto da Primeira Guerra Mundial na literatura brasileira.

HISTÓRIA DO LIVRO • ROMANCE

BRASILEIRO - SOCIABILIDADE

FEMININA • PORTO ALEGRE

- PRIMEIRA GUERRA MUNDIAL • VIVALDO COARACY.

\section{FRIDA MEYER:}

WOMEN'S SOCIABILITY IN 1920'S

PORTO ALEGRE

ABSTRACT This article presents the novel Frida Meyer (1924) by Vivaldo Coaracy from the perspective of the History of the Book, proposing links between the literary text and its graphic materiality. It then documents its publishing process, brings data to the study of its circulation, and discusses its first critical reception. Through the analysis of central elements of the plot, this article also seeks to elicit the reading of Vivaldo Coaracy's novel, attributing importance to the representation of women's intimate and social life, of Porto Alegre's urban environment and of the context of World War I in Brazilian literature.

HISTORY OF BOOK • BRAZILIAN

NOVEL • FEMALE SOCIABILITY •

PORTO ALEGRE • WORLD WAR I •

VIVALDO COARACY.

\section{SOBRE A AUTORA}

Milena Ribeiro Martins é professora associada do curso de Letras e do Programa de Pós-Graduação em Estudos Literários da Universidade Federal do Paraná (UFPR). Licenciou-se em Letras (1995), fez Mestrado em Letras (1998) e Doutorado em Teoria e História Literária (2003) na Unicamp. Atualmente, dedica-se ao ensino e à pesquisa dos seguintes temas e áreas: literatura brasileira, Monteiro Lobato, história do livro e da leitura, ensino de literatura, biblioteca escolar. Este texto é parte resultante da pesquisa de pós-doutorado conduzida ao longo do ano de 2015, no Instituto de Estudos Brasileiros-IEB da USP, sob supervisão do professor Marcos Antonio de Moraes. 


\section{LIVROS RAROS E ORDINÁRIOS}

Pesquisas sobre a literatura brasileira do início do século xx que tentam investigar obras pouco mencionadas pelos historiadores da literatura esbarram num obstáculo quase intransponível: a dificuldade de acesso a livros editados nas primeiras décadas do século xx, hoje já considerados raridades. Nem sempre houve reedições, e a baixa qualidade do papel fez com que as primeiras edições se tornassem muito frágeis. Rubens Borba de Moraes prenunciou o desaparecimento desses livros "ordinários":

Lembrem-se dos livros publicados em torno de 1922, na época da Semana de Arte Moderna. São tão "ordinários” que é quase impossível, hoje em dia, encontrar-se um exemplar sem manchas. Quase todos os livros impressos nesses papéis de qualidade inferior desaparecerão. Já se estão desfazendo. Os colecionadores de primeiras edições de autores brasileiros dessa época importantíssima vão ter muito trabalho. Será, em breve, mais fácil encontrar uma primeira edição do Caramuru, publicado em 1781, que um exemplar de Macunaíma, saído em $1928^{1}$. 
Figura 1: Capa da $1^{a}$ edição de Frida Meyer (1924). Dimensões do livro: $16,5 \times 12 \mathrm{~cm}$ [de acordo com o Dedalus, USP], $258 \mathrm{p}$. Exemplar pertencente à $\mathrm{BBM}^{2}$.

Se a pesquisa se vincula à história do livro e, portanto, perscruta a materialidade das primeiras edições em busca dos "efeitos produzidos pelas formas materiais" ${ }^{3}$, ou de elementos paratextuais que se vinculem aos sentidos dos textos, ou ainda de marcas físicas da sua circulação eventualmente tatuadas nos exemplares, a dificuldade se torna ainda maior.

Fora de eventuais estantes particulares e do comércio de raridades, algumas poucas bibliotecas preservam livros ordinários que continuam sendo objeto de estudo de pesquisadores insatisfeitos com o que é impresso a partir de uma lógica de mercado. E as bibliotecas virtuais ainda têm um acervo muito limitado, mesmo de obras que já pertencem ao domínio público.

A Biblioteca Brasiliana Guita e José Mindlin - BBM-USP, abriga uma significativa coleção de livros brasileiros editados nos anos 1920. Este artigo tem por objetivo apresentar e sugerir elementos para análise de um dos livros dessa coleção - o romance Frida Meyer, de Vivaldo Coaracy (Rio de Janeiro, 1882-1967), publicado em 1924 pela então prestigiosa Companhia Graphico-Editora Monteiro Lobato.

\section{EM TORNO DO TEXTO}

A capa do romance traz uma figura feminina desenhada a bico de pena ou técnica de efeito semelhante (Figura 1) ${ }^{4}$. Suas mãos, próximas ao pescoço, sugerem algum movimento, como se a mulher estivesse se arrumando. Os lábios entreabertos, quase num sorriso, e a expressão dos grandes olhos, tranquilos, talvez cansados, combinam com a ideia de movimento, de postura não estudada. A manga de seu vestido tem

1. A expressão "hoje em dia" se refere a meados de 1965 , data da $1^{a}$. edição do livro de Rubens Borba de Moraes, O Bibliófilo Aprendiz, p. 201.

2. As fotos que ilustram este artigo, todas amadoras, foram feitas por mim.

3. Roger Chartier, A Ordem dos Livros: Leitores, Autores de Bibliotecas na Europa Entre os Séculos xiv e XVIII, p. 8.

4. Cilza Bignotto informa que a capa é de autoria de J. Prado, capista de muitos livros editados por Monteiro Lobato. Embora não tenha encontrado sua assinatura nessa edição, convém deixar registrada a informação. (Cilza Bignotto, Novas Perspectivas Sobre as Práticas Editoriais de Monteiro Lobato (1918-1925), p. 365. Tese de Doutorado). 


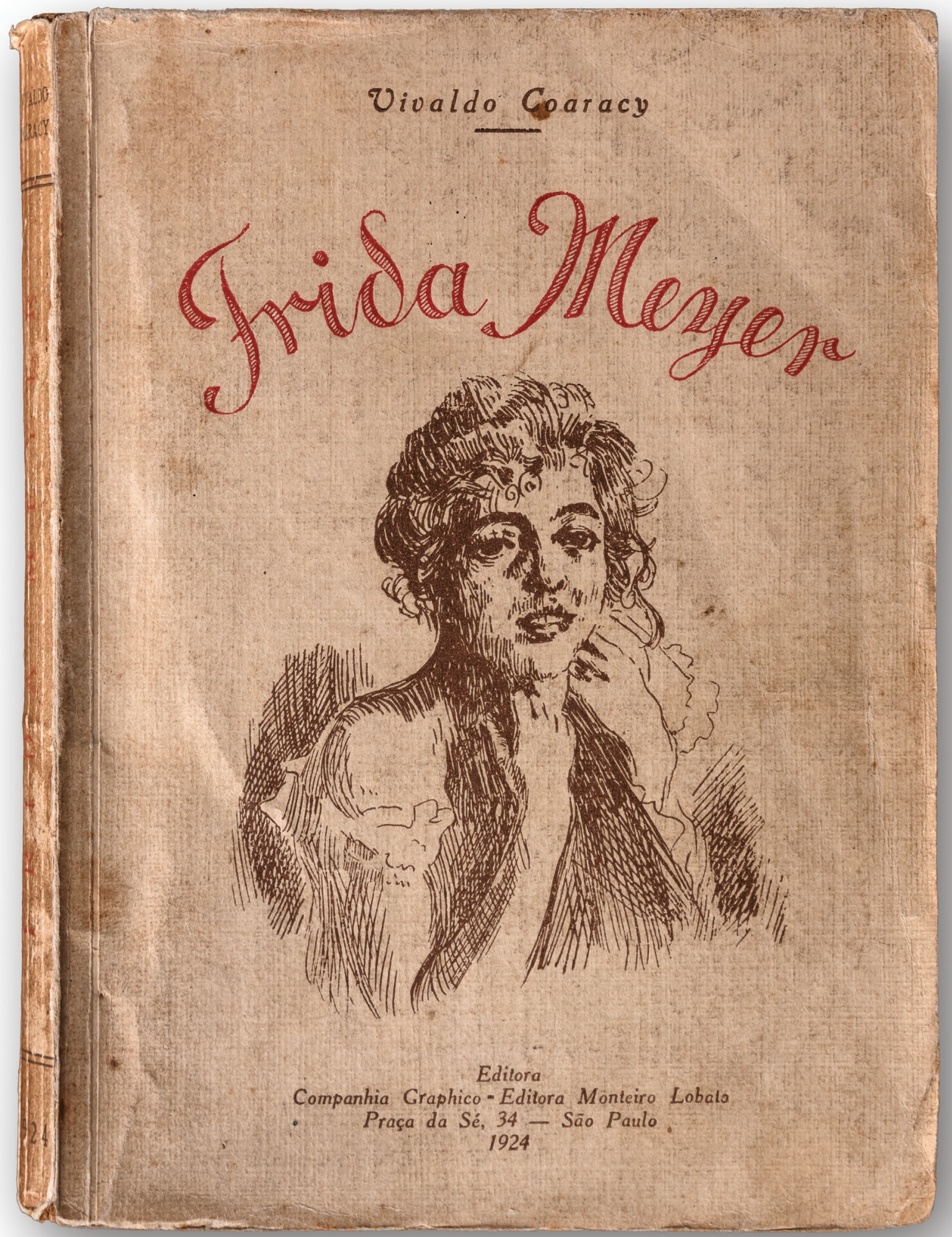

110

REVISTA BBM São Paulo n.1 pp. 106-132 jul./dez. 2018 
alguns babados leves que acentuam sua feminilidade e delicadeza. Pouco se percebe sobre a roupa da personagem, porque uma sombra cobre seu colo. Não há traços de fundo que sugiram um ambiente; os poucos elementos de sua postura, expressão e vestimenta, somados, sugerem antes um ambiente interno do que externo. A personagem dirige o olhar para a frente, para um suposto observador, que está fora da cena representada. No conjunto, a capa inicia a descrição da personagem título, ao dar ao nome uma fisionomia.

A título de comparação, lembremo-nos de Amar, Verbo Intransitivo, publicado em 1927, três anos depois de Frida Meyer. O idílio de Mário de Andrade guarda algumas semelhanças temáticas com o romance de Coaracy, seja pela centralidade da personagem feminina de origem alemã (uma nasceu naquele país, a outra descende daquela cultura), seja pelos discursos enunciados em ambas as narrativas a respeito de encontros entre povos oriundos de diferentes países, seja ainda pela vida doméstica e íntima que as duas narrativas desvelam.

Um estudo comparativo entre as duas obras ainda está por ser feito. Interessa-me, por ora, colocar lado a lado a descrição textual de Fräulein Elza e a descrição iconográfica de Frida Meyer.

O narrador de Amar, Verbo Intransitivo adia a descrição de sua personagem, por um lado alegando discrição e pudor, por outro, dando a seus supostos leitores a liberdade de criar cada qual uma imagem da personagem. Em seguida, descreve minuciosamente a sua Elza, dotando-a não apenas de forma física, mas também de movimento, intenções, instabilidade e densidade. O narrador descreve-a por aproximações e referências, menos do que por atributos fixos: compara-a imprecisamente a personagens de obras de arte, "Rembrandt, quasi Cranach" ${ }^{5}$, cogita sobre um destino que poderia ter sido o seu, caso sua vida não tivesse sido aquela ali narrada, e observa-a com um certo fascínio, tão magnetizado por ela quanto o adolescente Carlos. O resultado desse esforço descritivo é uma personagem densa e plural, de difícil apreensão, aspectos que são acentuados pelas comparações imprecisas: ("Si não fosse a luz excessiva diriamos a Betsabé de Rembrandt" ${ }^{6}$ ), pela estratégia de aproximação pouco categórica ("Quasi nem usa pó-de-arrôs", "duma calma quasi religiosa"7) e pela observação do que nela há de variável, de inconstante:

\footnotetext{
Mário de Andrade, Amar, Verbo Intransitivo: Idílio, p. 27.

Idem, p. 26.

Idem, p. 28.
} 
Que cabelos mudaveis! ora loiros ora sombrios dum pardo em fogo interior. Ela tem êsse geito de os arranjar que estão sempre pedindo arranjo outra vez. É engraçado! Bem alemã! Até nos cabelos. Só uma coisa os alemãis têm desta sapeca vivacidade latina: os cabelos que em geral os latinos trazem arrumados com regularidade alemã. Às vezes as madeixas de Fraulein se apresentam embaraçadas sôltas de forma tal que as luzes penetram nelas e se cruzam como numa plantação nova de eucaliptus ${ }^{8}$.

Através dessas estratégias, Mário de Andrade aproxima o leitor da personagem primeiro por meio de seus aspectos físicos, variáveis, para depois aprofundar o tema da variabilidade, instabilidade e pluralidade dos indivíduos (e personagens) numa digressão teorizante a respeito da constituição das personalidades:

Mas eu só quero saber neste mundo misturado quem concorda consigo mesmo! Não tem não. Somos misturas incompletas, assustadoras incoerencias metades tres-quartos e quando muito nove-décimos. [...] NÃO EXISTE MAIS UMA UNICA PESSOA INTEIRA NESTE MUNDO E NADA MAIS SOMOS QUE DISCORDIA E COMPLICAÇÃO.

Enquanto Mário de Andrade acentuou textualmente a densidade e variabilidade da sua personagem, a primeira edição do romance de Vivaldo Coaracy produz efeito algo semelhante por meio de sua imagem de capa. A figura que ilustra a capa do romance Frida Meyer tem o mérito de acentuar, pela sugestão de movimento, aspectos da variabilidade da personagem. Também colabora para esse efeito a técnica usada no desenho: a composição da figura por meio de traços atenua os seus contornos; a sombra que paira sobre o colo da personagem antes vela que revela, deixando espaço para suposições; o aspecto inacabado do desenho da mão esquerda tanto reitera a ideia de movimento, como também sugere a incompletude da descrição imagética.

Nesse sentido, a capa nos parece bem realizada por apresentar uma sugestiva construção de personagem que não se impõe sobre o texto, não atribui ao nome uma figura pronta, mas demanda a complementaridade do texto para responder a inquietações que a figura deixa em aberto: Para quem Frida olha? Em que ambiente ela se nos apresenta? O que nos dizem seu olhar, seu meio sorriso e seus gestos?

8. Idem, ibidem.

9. Idem, pp. 69 e 72. As maiúsculas são recurso expressivo do próprio texto ficcional. 
Desde as páginas iniciais, a personagem é flagrada em meio a um processo de mudanças derivadas de acontecimentos familiares, sociais e íntimos, com consequências comportamentais, morais e civis. A identidade de Frida Meyer será antes o resultado de uma trajetória do que um dado anterior aos eventos de sua vida. Essa afirmação não seria verdadeira para outros personagens do romance, apresentados de forma mais fixa e definitiva, como personagens mais planos do que esféricos. É o caso de Meyer, pai de Frida; de Madame Servine, dona de um salão de beleza que se torna pensionista e amiga de Frida; e também de Henrique de Freitas (usualmente o narrador se refere a ele apenas pelo sobrenome), empresário carioca, amante de algumas mulheres, inclusive da Frida. Todos esses permanecem os mesmos, apesar dos acontecimentos da trama.

Ainda quanto à capa, observa-se que pouco destaque foi dado ao nome do autor. Enquanto o título do livro se apresenta em forma de um ligeiro arco, com letra cursiva vermelha, numa caligrafia pouco convencional, composta por traços hachurados, o nome do escritor aparece no alto da página em letras pequenas, numa linha horizontal, sem destaque, da mesma forma que aparecem as informações sobre a editora e o ano da edição, na parte inferior da capa. Como se vê, combinam-se poucos elementos, em apenas duas cores, sobre um fundo que parece ter sido branco ou cru, o que produz um livro de aspecto discreto e elegante ${ }^{10}$.

Talvez o pouco destaque dado ao nome do escritor se deva ao seu desconhecimento no meio letrado paulista. Porém, Frida Meyer não foi a primeira obra literária de Vivaldo Coaracy editada em livro: em 1908 ele publicara o romance A Rampa ${ }^{11}$. Além disso, Coaracy devia gozar de algum prestígio no Rio Grande do Sul, já que ele era um dos membros de sua Academia de Letras ${ }^{12}$.

A quarta capa do livro traz apenas uma pequena ilustração, circunscrita por uma forma oval; dentro, um vaso de flores, do qual

10. A delicadeza da imagem da capa, é bom notar, não é reveladora de aspectos comportamentais da personagem, que podem ter sido considerados imorais naquele momento. Apesar da ousadia das atitudes de Frida (sobretudo no que diz respeito à sua sexualidade, mas também no enfrentamento da autoridade paterna e no controle da vida econômica da família), o tema da sexualidade feminina não é incomum na ficção brasileira dos anos 1920. Vide, por exemplo, Fruta do Mato (romance de Afrânio Peixoto, 1920), Madame Pommery (romance de Hilário Tácito, 1920), A Mulher que Pecou (contos de Menotti Del Picchia, 1922), Mademoiselle Cinema (romance de Benjamin Costallat, 1923), Amar, Verbo Intransitivo (Mário de Andrade, 1927), dentre outros.

11. José Ramos Tinhorão faz menção a esse romance, informando que A Rampa foi publicado em Porto Alegre, pelas Oficinas Gráficas da Livraria Americana, em 1908. Cf. J.R Tinhorão, A Música Popular no Romance Brasileiro, vol. ı: Séculos XVIII e XIx, p. 251. O site da Biblioteca Nacional permite saber que há lá um exemplar desse romance.

12. "Notas e Notícias", Gazeta de Notícias, n. 96, p. 1. Rio de Janeiro, 06.04.1910. Hemeroteca Digital Brasileira. Disponível em: <http://memoria.bn.br/DocReader/cache/487803382147//0022750-2Alt=002144Lar=0 01720LargOri=007271AltOri=009064.JPG>. Acesso em: 3 fev. 2016. 
pende uma corrente. No canto inferior esquerdo, um número identifica o exemplar: " $n^{\circ}$ 1958” (Figura 2). Não foi possível saber, no entanto, se o número corresponde a um procedimento editorial de identificação de exemplares de uma tiragem, ou ainda se corresponde a um procedimento de catalogação feito por um livreiro ou por um leitor.

O exemplar consultado traz, no verso da capa, um carimbo vermelho com informações de uma livraria portuguesa de livros usados; por isso considera-se a possibilidade de que o carimbo " $\mathrm{n}^{\circ}$ 1958", também em vermelho, tenha sido acrescido por essa livraria (Figura 3). $\mathrm{O}$ anúncio da livraria portuguesa permite tecer hipóteses acerca de caminhos imprevistos trilhados por livros brasileiros. Por enquanto, é só um dado curioso; a soma desse registro com outros indícios colhidos em outros livros da década permitirá atribuir novos e mais consistentes sentidos a hipóteses desse tipo.

Diferentemente de outros livros da mesma editora, o romance Frida Meyer não traz páginas de publicidade anexas ao texto. Também não traz outros elementos paratextuais, como dedicatória, epígrafe, sumário ou errata. Ao longo do texto, não há outros recursos gráficos expressivos. O único detalhe são as capitulares na abertura de cada capítulo - compostas por traços leves, elas ocupam o espaço de duas linhas do texto, sem adereços adicionais (Figura 4). As ausências aqui anotadas não fazem falta ao livro, cuja expressividade fica por conta dos recursos textuais.

A respeito dessa edição de Frida Meyer, Cilza Bignotto informa que o romance chegou à editora por intermédio de Léo Vaz. A primeira e única edição do romance saiu a público em 1924: em outubro desse ano, o jornal O Estado de S. Paulo anunciava o seu lançamento ${ }^{13}$. O momento em que o livro foi editado lhe era favorável: comemorava-se em 1924 o "centenário da imigração alemã no Rio Grande do Sul”14. Porém, a Companhia Graphico-Editora Monteiro Lobato faliu no ano de 1925, o que parece ter contribuído significativamente para o desconhecimento da obra. Segundo a documentação de Bignotto, em julho Lobato deu entrada no pedido de falência; e em agosto, quando Vivaldo Coaracy "declarou crédito na falência da Cia. Graphico-Editora Monteiro Lobato pela importância de um conto e duzentos mil réis"15, relativos aos direitos autorais contratados com o editor, havia 1457 exemplares

\footnotetext{
13. "Livros Novos", O Estado de S. Paulo, 28.10.1924, p. 5.

14. Lucas Flores Hayet e Ivânia Campigotto Aquino, "Frida Meyer: A História da Busca de um Romance Desconhecido", Anais Eletrônicos do /l Congresso Internacional de História Regional, pp. 1-8.

15. "Livros Novos", O Estado de S. Paulo, 28.10.1924, p. 5.
} 

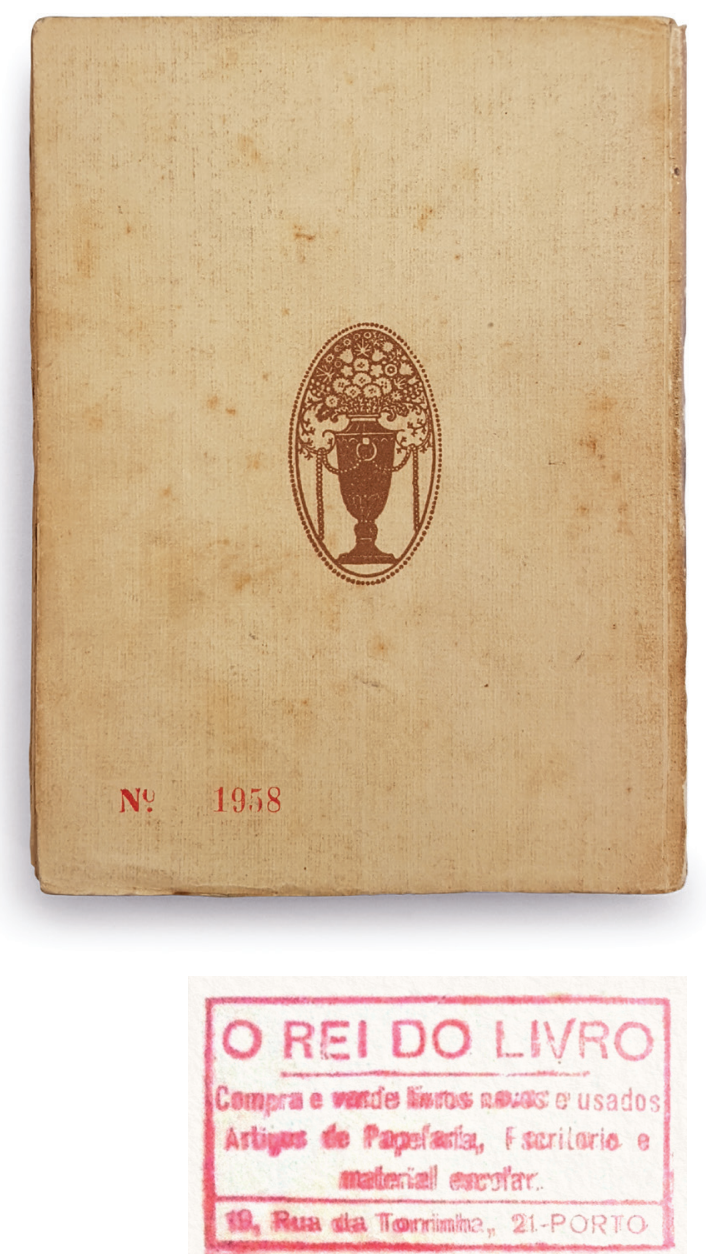

Figura 3. Anúncio carimbado na segunda capa do livro Frida Meyer, de Vivaldo Coaracy. Exemplar pertencente à BBM-USP
Figura 2. Quarta capa da $1^{a}$ edição

de Frida Meyer, de Vivaldo Coaracy.

Exemplar pertencente à $\mathrm{BBM}$.
DAHIA a tarde, grisalha e triste. Vinha de longe, vago, um prenuncio de chuva, no ar frio daquella primavera precoce. Em frente á janella aberta da sala de jantar, alem dos telhados da casaria que se despejava pela encosta abaixo, a faixa do rio tinha a placidez fosca duma chapa netalica; as ilhas fronteiras esboçavam-se, mal definidas, atravez duma escomilha de nebrina rala, cor de chumbo.

Sentada junto á janela, ás mãos sustentando o rosto, cotovelos apoiados aos joelhos, Frida estendia o olhar dos olhos ainda congestionados do pranto, sobre a paizagem tristonha. Tomava-a um acabrunhamento completo, todo o seu ser, alma e corpo, como $11 \mathrm{~m}$ trapo, e via na atonia cinzenta do dia o reflexo do seu proprio estado de espirito, o marasmo em que sentia esboroar-se-lhe a vida.

As duas visinhas que num movimento de caridade curiosa tinham vindo oferecer-se solicitas para ajudal-a a passar o transe, vendo-a naquela calma

5

Figura 4. Página de abertura do capítulo I, de Frida Meyer, de Vivaldo Coaracy.

Exemplar pertencente à $B B M-U S P$. 
do romance no estoque da editora - a tiragem havia sido de dois mil exemplares. Não se sabe qual foi o destino desses exemplares restantes: se ficaram atados à burocracia do processo, estocados num arquivo, ou se foram postos em circulação.

Em suas memórias, o escritor apresenta sua versão a respeito das circunstâncias da edição do romance:

O meu romance foi, creio, a última publicação da Editora Monteiro Lobato antes da falência em que submergiu a empresa. O trabalho nem chegou a ser lançado propriamente no mercado. A quase totalidade da edição foi arrolada entre os bens da massa falida. [...] Além disso, era livro de autor desconhecido. O seu desaparecimento em meio do fragor da falência sensacional passou despercebido. A crítica dele não tomou conhecimento. Apenas Sud Mennucci, em rodapé do Estado de S. Paulo, dele se ocupou muito favoravelmente, apontando-lhe qualidades. Caiu sobre a obra um silêncio sepulcral e a edição desapareceu não sei como. Muitos anos mais tarde, por acaso, no Rio de Janeiro, descobri meia dúzia de exemplares, já puídos pelo tempo, numa liquidação de alcaides da Livraria Freitas Bastos. Comprei-os ${ }^{16}$.

A análise desgostosa carece de algumas correções: Frida Meyer não foi a última obra publicada pela editora; outras obras foram editadas em 1925, que, do ponto de vista dos diretores, "prometia ser um ano bom para a Cia. Graphico-Editora Monteiro Lobato. Pelo menos é o que sugere o relatório [...] apresentado a seus acionistas em 7 de março de 1925"17. O livro parece ter tido de fato uma história muito breve, todavia, pouco mais de quinhentos exemplares da obra devem ter circulado, descontados os quase 1500 que fizeram parte da massa falida. A recepção do romance é difícil de documentar; sabe-se que, além do mencionado artigo de Sud Mennucci, houve pelo menos mais uma notinha a seu respeito num jornal carioca. Coaracy pode nunca tê-la conhecido, mas, dada a importância do signatário e as críticas que nela se apresentam, é provável que tenha preferido ignorá-la. Quem a assina é Osório Duque-Estrada, importante crítico, membro da Academia Brasileira de Letras, conhecido por suas polêmicas. O crítico considerou o romance "obra de pouco estilo e de nenhum interesse, que mal paga o leitor do sacrifício da leitura”. Para exemplificar seu juízo, sumariza a cena final do romance, transcreve-lhe um trecho

\footnotetext{
16. Lucas Flores Hayet e Ivânia Campigotto Aquino, "Frida Meyer: A História da Busca de um Romance Desconhecido", Anais Eletrônicos do /l Congresso Internacional de História Regional, pp. 1-8. 17. Bignotto, op. cit., p. 362.
} 
e comenta: “Termina com o incêndio das casas alemãs, ateado pelo povo da capital rio-grandense, no tempo da guerra. Podia ser essa uma página empolgante, se fosse tratada por mão de mestre”. O crítico ainda qualifica o romance como "descosido e desmanchado" e conclui desestimulando qualquer leitura: "Não é preciso, pois, perder muito tempo e papel com esta Frida Meyer de carregação"18.

Com a falência da editora, o romance parece ter caído no ostracismo.

Passados mais de noventa anos de sua edição, a leitura do romance parece hoje muito mais empolgante e relevante do que o crítico sugere. Ao selecionar um aspecto da obra - histórico e cultural - o crítico encobre suas outras faces, ocultando aspectos dignos de interesse, sobretudo relativos à vida doméstica, ao espaço da mulher na sociedade, a comportamentos e relações sociais, aspectos nos quais seu breve texto não toca. Além disso, a enunciação do desapreço pelo estilo do escritor acaba minimizando a importância do tratamento dado por ele ao ambiente urbano de Porto Alegre, cidade até então pouco explorada pela literatura - salvo melhor juízo. Então, seja por aspectos sociais e contextuais, seja por aspectos mais intimistas, que lhe são centrais, considero que Frida Meyer merece, sim, tempo e papel.

\section{LENDO 0 ROMANCE}

Frida Meyer contém cenas ao mesmo tempo vivas e breves, compostas por descrições plásticas e expressivas, além de diálogos bem construídos. Na primeira página do romance, o estado de espírito da personagem, em luto pela morte da mãe, reflete o cinza da tarde nublada:

Cahia a tarde, grisalha e triste. Vinha de longe, vago, um prenuncio de chuva, no ar frio daquella primavera precoce. Em frente á janella aberta da sala de jantar, alem dos telhados da casaria que despejava pela encosta abaixo, a faixa do rio tinha a placidez fosca duma chapa metalica; as ilhas fronteiras esboçavam-se, mal definidas, através duma escomilha de nebrina rala, cor de chumbo.

Sentada junto á janela, ás mãos sustentando o rosto, cotovelos apoiados aos joelhos, Frida estendia o olhar dos olhos ainda congestionados do pranto, sobre a paizagem tristonha. Tomava-a um acabrunhamento completo, todo o seu ser, alma e corpo, como um trapo, e via na atonia cinzenta do dia o reflexo do seu proprio estado de espirito, o marasmo em que sentia esboroar-se-lhe a vida ${ }^{19}$.

18. Osório Duque-Estrada, "Registro Literário", Jornal do Brasil, 12.8.1925, p.8.

19. Todas as citações do romance referem-se à sua primeira edição (salvo engano, a única): Vivaldo Coaracy, Frida Meyer, p. 5. Manteve-se a ortografia original do texto. 
Como se pode notar, o romance tem início com uma descrição adjetivada da natureza, em que a cor "grisalha", o ambiente nublado e a "paisagem tristonha" se associam ao luto vivido pela personagem Frida, por causa da morte de sua mãe. Essa associação entre o ambiente e as emoções da personagem parece hoje convencional; talvez também o fosse na década de 1920, mas nem por isso deixava de ser um recurso lírico com forte poder sugestivo. O mesmo recurso foi utilizado, por exemplo, no poema "Cartas de Meu Avô", de Manuel Bandeira, publicado em livro, sete anos antes do romance de Coaracy. Bandeira também associou, numa mesma imagem, a tristeza, a solidão e o luto à atmosfera cinzenta trazida pela chuva:

O meu semblante está enxuto.

Mas a alma, em gotas mansas,

Chora, abismada no luto

Das minhas desesperanças...

E a noite vem, por demais

Erma, úmida e silente..

A chuva em pingos glaciais, cai melancolicamente ${ }^{20}$.

O narrador descreve ora o que a personagem vê a partir de sua janela, ora a própria personagem, alma e corpo mergulhados na atmosfera cinzenta e enlutada. O movimento se faz a partir da paisagem para a janela; dali, um traçado panorâmico dirige o olhar para o casario e a geografia que o circunscreve e, em seguida, num movimento de interiorização, para dentro da casa onde está Frida, perfeitamente enquadrada naquela atmosfera. Como se vê, o movimento se dirige do externo e visível para o íntimo e sensorial - o que sugere a inclinação intimista do romance.

Como é de se supor, a personagem-título é a mais investigada de todas elas. Outras se dão a conhecer quase que exclusivamente a partir dos olhos de terceiros. É o caso da mãe de Frida e Ernesto, apresentada pelo recurso à memória de seus filhos mais velhos, que muitas vezes a haviam surpreendido chorando:

[...] num choro silencioso e triste que eles não compreendiam e que ela lhes não explicava. Depois, ou se resignava ou ocultava mais cuidadosamente esse externar de maguas. Nunca mais a tinham visto chorando e a imagem que dela guardavam e que agora havia de permanecer pelo resto de 
suas existências era a duma mulher magra e pálida, sempre triste, creatura apagada que não sorria nunca, tibia e sem vontade, com explosões intermitentes de afecto pelos filhos, sem interesses na vida. [...] Nesses quatro anos de convivência constante [Frida] apenas percebera, sem jamais ouvir-lhe um queixume, que a mãe encarava a existencia como se fosse uma punição, castigo em que estivesse a purgar um pecado antigo. Meyer desposára-a por interesse, pela pequena fortuna que possuia ${ }^{21}$.

O narrador pouco mais dirá sobre essa mulher, mas seus poucos traços fazem dela um tipo facilmente reconhecível nas famílias brasileiras tradicionais. Frida, por sua vez, seria menos tradicional, como se verá a seguir.

Ainda quanto às memórias infantis de Frida e Ernesto, é curioso observar que a imagem de sua escolarização é bastante positiva - é distinta de outras imagens que se construíram sobre processos de escolarização desde pelo menos finais do século XIX até hoje, imagens em que a escola é caracterizada como espaço de violência, enquadramento e conformação. Em Frida Meyer, a escolarização da menina representa um intervalo de relativa liberdade e prazer, de superação em vez de conformação, porque abre a ela a possibilidade de um destino diferente do da mãe: "A escola fôra um prazer, porta que se abria para fugir á atmosfera da casa. Quando completára os quatorze anos, Frida havia deixado o colegio; passára a auxiliar a mãe nas lidas quotidianas" 22 .

Em outros episódios, outros relances do período escolar são apresentados: foi no internato que Frida teve suas primeiras lições extracurriculares sobre sexualidade, e foi lá também que tomou consciência do envolvimento sexual entre meninas.

Justapostas numa mesma página, as duas cenas da infância de Frida - a infelicidade silenciosa da mãe e a escola como possibilidade de fuga do ambiente familiar - ajudam a explicar sua determinação em não repetir a trajetória da mãe e, em vez disso, inventar outra para si. Num primeiro momento, seu plano parece dos mais conservadores: Frida vê no casamento "a porta por onde fugisse áquela existencia" 23. Sua trajetória para atingir esse objetivo não é particularmente romântica; tende a ser mais pragmática, a ponto de o narrador qualificar seu amor por Germano como "mais cerebral do que emotivo" ${ }^{24}$. 
A primeira preocupação de Frida, porém, não é arranjar um marido, mas obter sustento próprio e para suas irmãs menores. O padrão mínimo de conforto que ela almeja e as dificuldades que enfrenta para alcançá-lo aproximam esse romance de outros em que personagens pobres lutam para garantir seu sustento e alguma dignidade. Como o protagonista de Os Ratos (1935), de Dyonélio Machado por exemplo, para aproximar dois romances ambientados em Porto Alegre, Frida também se preocupa com os credores:

Mas o problema imediato, urgente, era outro. Cumpria manter a casa, pagar o colegio das irmãs, satisfazer parcialmente a sua necessidade de vestir bem, gota d'agua com que procurava enganar a sua sêde de luxo; encontrar meios de viver a todo custo, que as dividas creciam e ela não sabia que mais desculpas inventar para apresentar aos credores ${ }^{25}$.

Outros personagens pobres, que lutam prosaicamente pela sobrevivência, estão representados na produção ficcional mais conhecida daquela década - como no conto "Imposto Único" de Cidades Mortas (1919), de Monteiro Lobato, em Histórias e Sonhos (1920), de Lima Barreto, ou ainda em Brás, Bexiga e Barra Funda (1927) e Laranja da China (1928), de Alcântara Machado. No caso desses dois últimos, a semelhança com relação a Frida Meyer deve-se também ao tema da imigração.

Essas aproximações indicam o interesse nada secundário, na literatura dos anos 1920, pelo cotidiano de personagens pobres, pela sua preocupação com a sobrevivência cotidiana. Em vez de heroísmo - se por heroísmo entende-se um conjunto de atos sobre-humanos e ímpares - ganha espaço a rotina prosaica de sobrevivência e sustento, de busca de estratégias pragmáticas de ganhar dinheiro. O assunto não é novo, como se vê: é herdeiro de preocupações realistas que não perderam sua força na década de 1920, e que teriam continuidade na década seguinte, com inclinação política mais acentuada.

Não parece haver espaço, nesse universo, para soluções folhetinescas, nas quais o dinheiro advém da sorte grande ou de herança providencial. É o mundo do trabalho, portanto, convertido em matéria ficcional, especialmente o trabalho cotidiano de classes e grupos desfavorecidos, sem louros, com pouco dinheiro e sem grandes prazeres.

Até a prostituição tem espaço no rol de profissões "comuns" - isto é, de baixo prestígio e geralmente baixa remuneração. Em Os Caboclos (1920), de Valdomiro Silveira, mulheres atuam como prostitutas e como 
comerciantes. No conto que dá nome ao livro A Mulher que Pecou (1922), de Menotti Del Picchia, a prostituição é a alternativa encontrada pela mulher para angariar o dinheiro suficiente para tentar trazer de volta o marido, que estava na guerra. E, num caso mais extremo, em Madame Pommery (1920), de Hilário Tácito, a prostituição se apresenta como empresa inicialmente individual que se instala, cresce e prospera ao longo da narrativa, com sua engrenagem sendo apresentada com minúcia. Dessa minúcia, não escapam os preços, as taxas e o livro-caixa.

No romance de Vivaldo Coaracy, o dinheiro necessário para o sustento da família aparece desde as primeiras páginas, quando o narrador se refere à vida conjugal dos pais de Frida: "Meyer desposára-a por interesse, pela pequena fortuna que [ela] possuía”. Nas mãos do marido, mau negociante, o pequeno capital não rende, e a vida da mulher (sem amor e sem dinheiro) passa a ser encarada como um suplício: "a mãe encarava a existência como se fosse uma punição, castigo em que estivesse a purgar um pecado antigo" ${ }^{26}$. A percepção da vida pós-casamento, percebida como resultado de um pecado antigo e não identificado, acende a possibilidade de uma interpretação cristã do destino feminino e familiar, da adequação da mulher a um modelo pré-traçado, repetido, sem livre arbítrio. Com a morte da mãe, a punição pelo metafórico pecado tende a recair sobre Frida, que passa a gerir a casa e educar as irmãs caçulas, Olga e Elsa, submetendo-se inicialmente ao pai e ao irmão, que, embora controlassem o dinheiro, não se sentiam responsáveis pelo sustento da família toda:

Em casa [o pai] era todo espinhos, mais rude e mais grosseiro, exigente e rixento, semeando de azedumes a alma da filha. Cada vez que esta vinha pedir- lhe dinheiro para fazer face ás despesas domesticas, a irritabilidade de Meyer alvoroçava-se, violenta. A devorar o pequeno capital que pescára na venda da loja, reservava-o para a satisfação do seu egoismo e todo apelo ao mesmo para a vida da familia provocava nele erupções de colera. Multiplicavam-se as recriminações, começando pela acusação de gastos exagerados e esperdicios e terminando sempre por perguntar até quando julgavam os filhos que era obrigação dele o sustental-os. Que trabalhassem! tratassem de ganhar a vida!... Ela [Frida] recorria então a Ernesto [o irmão] e este acudia-lhe ás vezes, mas resmungando sempre: já fazia demais; o seu ordenado era pequeno e não podia andar carregando toda a familia ás costas!...27

É então que Frida projeta seu casamento como uma solução. 
Antes disso, ela promove uma pequena mas significativa transformação na casa da família e em sua própria vida, fazendo os arranjos e ajustes necessários para convertê-la numa pensão, por meio da qual ela assumiria o controle financeiro da vida familiar. Liderando tanto quanto possível o seu destino, Frida recusava a repetição do destino da mãe, representante das mulheres de seu tempo e de sua classe. A recusa enfrenta oposição do pai, que, dentro do esperado, reage com violência às atitudes da filha ${ }^{28}$. No entanto, como ele deixara de ser o provedor, sua autoridade e seu poder aos poucos se esvaziariam. A reação do pai não é de todo inesperada: o esvaziamento do seu poder tem por consequência o recrudescimento da violência moral e física contra a filha.

Frida não age de maneira revolucionária, já que seu reino continua sendo o ambiente doméstico; mas a transformação é importante porque ela faz das tarefas domésticas uma fonte de renda e de novas relações, além das limitadas relações familiares. Frida age, então, dentro dos limites permitidos e previstos para as mulheres naquele momento. Mas fica claro que seu desejo ultrapassa os limites do que era praticável:

Era demais! Frida jurava a si mesma que isso havia de acabar, e acabar já. Sentia-se incapaz de aturar mais tempo aquela situação, impelida ás resoluções extremas e radicaes. As horas corriam, marcadas em pancadas graves pelo relogio da sala de jantar, e ela, supercilios franzidos na concentração de todo o seu pensamento, revolvia planos e projectos que iam todos esbarrar diante do muro da impraticabilidade. Ah! si tivesse a coragem para enfrentar a vida sósinha!... Como poderia agarrar aquelles trez ou quatro contos de suas economias e fugir, ir para longe, para uma grande cidade, tentar a vida! Como uma mulher independente, sem atilhos e sem responsabilidades! Mas nunca poderia fazer isso. O seu temperamento, as suas ideas, a sua educação, tudo se erguia contra semelhante passo com os argumentos do mêdo, da falta de confiança em si, do horror do escandalo, do conhecimento da própria inaptidão, das suas ambições de existência burguesamente ordenada. E outros planos iam se delineando, menos aventurosos, mais praticos... ${ }^{29}$

A percepção do espectro de possibilidades existentes entre o que era socialmente aceito e o que Frida efetivamente desejava dentro dos modelos de vida feminina é construída, em grande parte, pela observação e pelo contato com os hóspedes da sua pensão familiar. As novas relações estabelecidas por ela com seus hóspedes (sobretudo com Mme Servine, 
Germano e Freitas) e as conversas e experiências que eles lhe oferecem permitem-lhe romper os limites de sua posição social e aspirar a mais do que ela mesma julgava praticável. "Mais" não no sentido financeiro ou material; mas sobretudo no sentido moral, emocional e afetivo: Frida desejava dinheiro para o sustento de si e de sua família, mas desejava sobretudo maior liberdade e independência.

Tal rompimento de expectativas sociais se faz também por meio de segredos, do ocultamento de ações moralmente condenáveis naquele momento e naquela sociedade, sobretudo envolvendo sexo fora do casamento, relações afetivas que não tinham por fim o casamento, a ocorrência de gravidez indesejada, a prática de aborto como solução. Assuntos íntimos, sejam potencialmente escandalosos ou apenas limítrofes no que diz respeito ao éthos de um grupo social, parecem ser mais comuns em obras de ficção do que em páginas de jornais. O autor corria o risco, ainda naquela época, mesmo depois da existência de tantos romances naturalistas, de ver sua obra qualificada como licenciosa, inadequada para leitoras.

Terá sido esse o caso de Frida Meyer? O crítico Sud Mennucci parece considerar que sim, embora não se estenda muito sobre o tema: "dá a impressão de que elle [o autor] carregou um pouco demais nas tintas, principalmente libertinas" ${ }^{30}$. Resta saber quão flexíveis ou estreitos eram os padrões morais desse crítico em relação aos seus contemporâneos.

30. Sud Mennucci, “Bibliographia”, O Estado de S. Paulo, 18.4.1925, p. 3.

Nesse seu texto, que ocupou um terço da página do jornal, o crítico dedicou-se a elogiar o trabalho do editor Monteiro Lobato e a resenhar obras editadas pela Companhia Gráfico-Editora Monteiro Lobato. O último livro apresentado e comentado por ele foi o romance de Coaracy. Reproduzo a seguir as considerações do crítico sobre o romance, por ser (até onde se saiba) o primeiro e o principal documento da recepção do romance Frida Meyer:

"[...] temos agora um romance sobre costumes sul-riograndenses, a que o seu autor, o sr. Vivaldo Coaracy, deu o título de 'Frida Meyer'.

"É um estudo sobre a influência social exercida pela colônia alleman naquele longinquo Estado e que o A. focalisou na cidade de Porto Alegre.

"Digamos, de entrada, que o exame das tendencias que ele descobre na actuação dessa colonia, não é amável e dá a impressão de que elle carregou um pouco demais nas tintas, principalmente libertinas.

"O livro permanece, comtudo, um romance singularmente interessante, já pela trama do enredo, que o A. soube graduar e escalonar com habilidade, já pelo desenvolvimento dos typos que vivem e se movem realmente, como os quer Sem Beneli 'stranamente accesi di luce interiore', já pelo estilo sóbrio e nervoso, em que o dialogo tem um lindo efeito, já ainda pelas idéas que o A. defende e que se escondem atrás do personagem sympathico que é Arthur Grimm ou então através da conversa doutrinaria desse juiz integro, profundamente bom que é o sr. Aguiar, idéas essas que ha pontos de vista originaes e paradoxos esfusiantes e que demonstram, além de uma cultura solida, um cérebro habituado a raciocinar com largueza e com independencia.

"Um personagem do livro do sr. Vivaldo Coaracy chama a atenção pelo cuidado e pelo carinho com que foi criado: é o Freitas.

"Temperamento mobil e irrequieto, com essa volubilidade que lhe traz a tentação absorvente da aventura amorosa, de que se acha possuído, tem entretanto, um fundo onde se percebe o bom estofo de uma alma de idealista.

"E é tão tentador o perfil desse homem que o A. [trecho ilegível] ter, pelo próprio título, arvorado Frida Meyer no papel de protagonista [ilegível] entregal-a, talvez [trecho ilegível] temente, ao Freitas.

"É esse um reparo que não podia deixar de ser feito. / Sud Mennucci." 
As novas relações propiciadas pela abertura da casa, pelo aumento e diversidade da circulação de pessoas, são um dos elementos centrais do romance de Coaracy, que tematiza também relações sociais fora da pensão, nas ruas de uma Porto Alegre multicultural, na qual se encontram imigrantes de várias nacionalidades e na qual se ouvem discursos sobre imigração e contatos interculturais.

O Hotel Moderno, o Clube Germânia, a rua e, em pequena escala, a pensão são os lugares de encontros mais plurais. No breve retrato que faz do hotel, o narrador menciona uma criada portuguesa, um porteiro castelhano e um garoto ascensorista (supõe-se que seja brasileiro), que assobia uma canção popular. A música popular aparece associada a uma classe trabalhadora brasileira, e também aparece sem grande desenvolvimento, como um elemento do ambiente, uma trilha sonora que contribui para a crônica urbana e para dar um tom à cena. Na casa de pensão, a modinha popular é entoada pela cozinheira mulata.

No quadro das nacionalidades que compõem a população desse romance, há também a espanhola Joana Huerta, comerciante de "drogas sem rótulo" e praticante de "cirurgia clandestina e criminosa" ${ }^{31}$, palavras pelas quais o narrador se refere às práticas clandestinas do aborto e da medicina.

A observação dos tipos sociais se dá de forma associada à construção dos espaços urbanos e suburbanos por onde essas figuras circulam, espaços que elas ajudam a construir. Não há uma caracterização minuciosa nem pitoresca das regiões da cidade; predomina a simples menção a lugares, ruas e bairros da cidade de Porto Alegre: Rua da Praia, Rua Sete, Rua Venâncio Aires, Rua da Ponte, Rua Tomaz Flores, Praia de Belas, Várzea, Azenha, Menino Deus, Santa Teresa etc. No caso da personagem espanhola, por exemplo, o narrador informa apenas que ela morava na "Rua da Alegria, não longe da Santa Casa". Se a referida rua hoje não tem mais esse nome, a história nos ajuda a entender a significativa localização da personagem: nas proximidades de um hospital e num local de má fama ${ }^{32}$, o que condiz com sua atividade profissional, marcada tanto pela prática da medicina clandestina como também por aspectos moralmente condenáveis naquele início de século.

\footnotetext{
31. Frida Meyer, p. 189.

32. A respeito da Rua da Alegria, Eloy Terra informa que ela também fora conhecida como rua do Arco da Velha, e que pessoas "mais respeitáveis" costumavam evitá-la: "Mulheres com o rosto carregado de pinturas e com roupas muito ousadas para os costumes da época, ficavam nas portas e janelas acenando para os homens que por ali passavam. Um escândalo! Tanto pela presença das mulheres, como pela localização da rua. Em pleno centro de Porto Alegre. Algumas pessoas se queixavam, mas as autoridades nada faziam" (Eloy Terra, As Ruas de Porto Alegre, pp. 91-92).
} 
Mais de uma vez, as zonas menos nobres da cidade são apresentadas pelo narrador. Poucas páginas depois, ele introduziria mais uma personagem secundária, localizando-a em outro pedaço aparentemente obscuro de Porto Alegre, assim caracterizado:

Ha nas cidades certos bairros que ficam esquecidos. Lá não chega o bafejo da brisa que faz com que ruas se transformem, casas naçam, creçam e morram, abrindo logar a outras. Eles permanecem, estratificados, na fossilização das cousas olvidadas. E a propria gente que neles vive parece também mofada.

D. Mariquinhas Pontes, na severidade modestíssima do seu eterno vestido de merinó de algodão, parecia embolorada. Nem se poderia compreender que ela vivesse noutro logar que não naquelas adjacências do Alto da Bronze, de ruas sinuosas e tristes, de velhas casas de telhados acurvados ao peso das memorias do tempo em que o bairro dos guabirús tinha pretenções a zona aristocratica, vendo-se-lhe desenvolver em torno o incipiente Porto dos Casaes $^{33}$.

Alheios às ações revitalizadoras da belle époque, o bairro e seus moradores permanecem parados num tempo que parece ser antigo, em ruínas. Habitada por moradores que lembram os personagens suburbanos de Lima Barreto, essa região da cidade - central, mas pouco valorizada - guarda ainda mais semelhanças físicas com o aspecto de ruínas das cidades mortas de Monteiro Lobato. O bairro, que parece pertencer a um tempo passado, carrega em si as marcas do abandono. Esquecido pelo poder público e por iniciativas privadas, ele sobrevive no tempo presente da narrativa, mas transformado pela ação do tempo - fossilizado, embolorado, mofado. No entanto, também é continuidade, permanência, espaço transformado fisicamente pelo tempo, não pelo poder público ou por iniciativas privadas. A região empobrecida não passou por transformações modernizantes; não é vitrine de novidades. Pelo contrário, abriga antigos moradores, antigos costumes que sobreviveram a despeito da passagem do tempo, salvaguardados na penumbra de bairros desprestigiados, de ruas com a fama de serem mal frequentadas. Significativamente, é lá que Freitas encontrará um espaço seguro para seus encontros com uma mulher casada, Erna Lang (que, quando solteira, com o sobrenome Busch, fora colega de escola de Frida Meyer).

Freitas é um empresário carioca bem-sucedido, que se mudara para Porto Alegre depois de uma "aventura escandalosa" 34 vivida no 
Rio de Janeiro. Sua escandalosa reputação continua sendo construída na cidade gaúcha, onde ele se relacionará com mulheres solteiras e casadas, dando continuidade ao traço mais marcante de seu caráter. Sua ação acontece em geral discretamente, mas a cidade acaba sabendo por meio de conversas de homens em bares ou de mulheres em salões de beleza. Erna, sua amante, é menos discreta, e acaba colocando em risco a sua reputação e a de Freitas. Quando o envolvimento dos dois ameaça se tornar fato notório, ela viaja, salvaguardando um pouco sua imagem e a do marido.

Essa zona menos nobre da cidade é identificada, então, como lugar ideal para a permanência de práticas tradicionais, como o adultério, o sexo fora do casamento, o aborto e a prostituição. Tais práticas contrariam valores morais presumidos (a fidelidade das mulheres casadas e a virgindade das mulheres solteiras), mas não os desafiam nem os confrontam publicamente. É o espaço da surdina e das sombras, do quase segredo, daquilo que, não sendo oficial, é sabido, é comentado e que constrói reputações. Assim como o poder público demora a chegar a esses desvãos não afetados pelas iniciativas modernizadoras, ignorando-os e deixando-os à margem, o conhecimento público do que ali se passa demora a se tornar oficial, ainda que muitos falem sobre ele.

A fama de Freitas o acompanha, como um traço definidor. Quando ele se apresenta para alugar um quarto na pensão de Frida, seu irmão logo levanta sua ficha, junto a caixeiros viajantes, os quais apresentam seu passado, sua fama de mulherengo e, ao mesmo tempo, de bom pagador, de homem cortês e discreto. São esses últimos atributos que prevalecem na sua rápida aceitação, ao lado da necessidade de conseguir seus primeiros hóspedes.

A segunda hóspede da pensão viria a ser a desconhecida Mme Servine, sobre quem nada se sabe e pouco se pode presumir. Ela desperta desconfiança em Ernesto e curiosidade em Frida:

[...] seus modos bruscos, tics nervosos, maneiras masculinas, cabelos evidentemente oxigenados, trajo sempre apurado. Era impossivel dizer-lhe a edade, como impossivel fôra precisar-lhe a nacionalidade. O nome podia indicar mais duma pátria; o sotaque era indefinível, como o perfume de que usava; a camada de cold-cream e carmin e os toques de diversos lápis tanto podiam estar sobre um rosto de trinta como de quarenta anos. Os olhos, em momentos raros de abandono, tinham o olhar cansado de quem tivesse vivido intensamente ${ }^{35}$. 
Mme Servine reúne em si atributos e sotaques diversos, sem deixar evidentes seus traços culturais originais. Sua origem parece ser a modernidade: ela é mulher de um tempo, não de um lugar. Aos olhos de hoje, seu nome e sua descrição evocam metrópoles europeias, mas ela poderia ser um tipo carioca profundamente impregnado por aspectos parisienses, da mesma forma que os tipos gaúchos que povoam o romance se esforçavam por construir uma identidade alemã. Mme Servine viera a Porto Alegre para abrir um salão de beleza, o que é bastante condizente com sua imagem artificial, com seu estilo construído à custa de tintura, maquiagem e perfume. O artifício e a dissimulação, porém, não a tornam menos digna da confiança de Frida. Do alto de sua misteriosa experiência de vida, Mme Servine se converte em conselheira de Frida, a quem ajuda e conduz em momentos de crise: quando Frida engravida de Germano, Servine a leva para fazer um aborto; e quando Frida está prestes a ser abandonada por Freitas, Servine sugere-lhe uma estratégia para segurar o rapaz. Da primeira vez, sua intervenção é bem-sucedida; da segunda, não.

Além das suas ações, interessam também as opiniões que Servine divide com Frida, nas duas crises em que Frida se via diante de sério risco de desonra pública. Primeiro, quando Frida, desesperada, revelou-lhe que estava grávida, a mulher experiente colocou o problema íntimo numa perspectiva menos individual:

Para tudo ha remedio. Então a Frida pensa que é a primeira a quem acontece um desastre desses?... Minha cara, infelizmente isto é uma cousa de todos os dias e ninguém morre de desespero por essa causa. O que é preciso é agir enquanto é tempo... Foi o diabo, lá isso foi; mas é sempre assim. Lembra-se do que lhe disse um dia no meu consultorio? Dizia-lhe eu que as mocinhas sempre dão essas cabeçadas por sentimentalismo, por amor aos namorados... Eu receava que isto viesse a acontecer... Mas já agora o que a a fazer é tratar de remediar o mal antes que seja tarde ${ }^{36}$.

E, depois, quando Frida se percebera prestes a ser abandonada por Freitas, depois que um acidente culminou com a revelação pública do romance dos dois, Servine filosofa a respeito dos homens em geral, mais uma vez movida pela experiência de vida e de mundo que ela tem e Frida não tem: 
Ah! minha cara, os homens!... A suprema lei para eles, para todos eles, é o seu infinito egoísmo e o meio que temos de realmente dominal-os é saber torcer esse egoísmo em nosso proveito. Enquanto não aprendemos a despresal-os no nosso intimo, a todos igualmente, não podemos ser fortes na vida. E a minha amiguinha está agora nas primeiras classes da escola em que se aprende isso; compreende? ${ }^{37}$

Frida considera Mme Servine como um exemplo de mulher livre. Quando sonha com um futuro, Frida se espelha em sua confidente e deseja, por um momento, viver sozinha, numa cidade grande, sem família e sem outras responsabilidades que não o próprio sustento. O desejo lhe parece utópico, sobretudo porque é dela a responsabilidade pela criação das irmãs. Seu vínculo com sua família e, provavelmente, sua limitada experiência de mundo, fazem com que suas aspirações fiquem circunscritas a Porto Alegre, aos círculos sociais que ela conhece e nos quais aspira viver. Em outras palavras, Frida não só tinha raízes em Porto Alegre, como também esperava mantê-las. Em seu desejo de liberdade, ela sonhava sair dali, imaginava que se sentiria mais livre se fosse independente, mas percebia que esse desejo era uma utopia.

As aspirações de Frida sugerem a busca por uma maior independência feminina. O rumo de suas ações, porém, acaba sendo conservador: seguindo a prática de seu pai e irmão, que encontraram maneiras de extorquir Freitas, Frida também passaria a demandar que seu parceiro a sustentasse, que lhe presenteasse; ela inclusive deixa de investir na pensão para fazer de seu relacionamento sua fonte de renda. No entanto, ela oscila: uma tendência conservadora no que diz respeito ao sustento financeiro, e uma tendência libertária sobre a exposição de sua intimidade, que ela não faz questão de esconder. Vez ou outra, Frida se torna explicitamente contrária a certas convenções sociais - o que, como era esperado, lhe traria consequências:

Resultavam dahi atitudes, frases, modos de agir que ao Freitas punha muita vez embaraçado em presença de estranhos. Ela parecia não querer fazer mistério da posição reciproca de ambos e, si não a alardeava positivamente, não fazia tambem o mínimo esforço por ocultal-a a olhos de mediocre perspicacia ${ }^{38}$.

37. Idem, p. 225.

38. Idem, pp. 198-199. 
Depois que seu relacionamento íntimo com Freitas se tornou notícia, Frida sentiu na pele a rejeição do grupo social do qual gostaria de participar:

O ostracismo a que se viu aturada por aquele mesmo circulo social que invejava e a cujo ambito aspirava, a condenação diariamente manifesta por aqueles em cujo meio desejara viver, só concorriam para a desmoralizar a seus próprios olhos ${ }^{39}$.

Como solução, ela acaba dando um passo atrás nas suas aspirações libertárias, aceitando a solução apresentada pelo amante: casar-se com Germano, seu antigo namorado, que havia voltado para a cidade às escondidas, sem sucesso e empobrecido. Frida e Germano contarão com o apoio financeiro do amante, que os auxiliaria financeiramente, satisfazendo suas necessidades e caprichos com alguns contos de réis.

O casamento ainda se apresenta como a solução mais segura para o destino de Frida e de outras mulheres que, como ela, haviam se permitido viver sua afetividade e sua sexualidade fora e antes do casamento. O casamento é, portanto, solução nada romântica, capaz de apagar ou esconder aquilo que era visto como deslize moral, mau comportamento para mulheres. A respeito desse destino comum a mais de uma mulher, Freitas filosofa, repetindo frase já ouvida da boca de um amigo: "As mulheres antigamente refugiavam-se num convento; hoje refugiam-se no casamento..." 40

A frase aplica-se bem, neste romance, a diferentes mulheres, como a própria Frida, Alice (filha de amigos de Freitas) e Erna. A esta última, o casamento serve inclusive de justificativa quando o amante investiga com quem ela teria aprendido certas práticas sexuais:

[...] na intimidade, depois da posse, começára a invadil-o rapido o enjôo. Depravado embora, como era, chocava-o, escandalisava-o quase, o despudor com que ela se entregava. Não era sensual; era laciva. Tinha atitudes, gostos, intimidades de barregan vulgar, sem a sombra dum vestigio de respeito próprio. E um dia, quando ele no enervamento da saciedade, sem se poder conter, lhe perguntára, curioso, quem lhe havia ensinado todas aquelas finuras de alcouce, ela desfolhara uma das suas risadas sonoras, respondendo: 
- Ora, quem havia de ser?... Meu marido! Pensas que essas coisas se aprendem no colegio?... ${ }^{41}$

Embora Freitas não desconfie, os leitores sabem que Erna tinha se envolvido sexualmente com algumas meninas, justamente no seu tempo de escola ${ }^{42}$. Sua resposta incomoda o amante, mas faz rir aos leitores, sabendo que Erna não divide com seu amante toda a sua intimidade, não lhe revela toda a sua história.

Nem mesmo Freitas está livre do julgamento social. Ele próprio não é capaz de ignorar o desprezo com que alguns amigos passam a tratá-lo. Sua situação parece se resolver mais facilmente, seja porque sobre o homem recaíam outras expectativas, seja também porque ele é forasteiro, porque não tem tantas raízes com a cidade. Preparou sua partida de Porto Alegre para logo depois do casamento de Frida, assim como já deixara o Rio de Janeiro em função de outros escândalos.

A propósito, a situação de Freitas como forasteiro, com limitadas relações na cidade, converte-o num observador privilegiado, disposto a dividir com alguns amigos suas críticas ao modo de vida da colônia alemã de Porto Alegre. É com aversão que o carioca observa os brasileiros de ascendência alemã que compunham boa parte da sociedade do romance:

Chegando ao sul [Freitas] fôra, como todo o recem-vindo de outros Estados, tomado de violenta repulsa por aquele tipo, para ele desconhecido, de brasileiros natos que ignoram a língua do paiz, que não perdem oportunidade de manifestar o seu superior desdém por tudo quanto e nacional e que se dizem ainda na terceira e quarta geração, alemães, olhos voltados para a 'Grande Patria' de além-mar, todas as ambições para lá volvidas, de lá recebendo todas as inspirações e todas as ideas, enquanto prosperam na despresada terra que lhes é berço e que lhes dá vida ${ }^{43}$.

A observação mais ácida sobre esses brasileiros, que constituem a maioria da população do romance, é feita por um observador de fora, por alguém cujo distanciamento cultural propicia um olhar distinto, devido à falta de convivência com aquele universo. Por meio de observações como essa, o romance abre espaço para discursos nacionalistas,

\footnotetext{
41. Idem, p. 104.

42. Idem, pp. 34-35

43. Idem, p. 29.
} 
que explicitam problemas decorrentes da imigração e apresentam propostas de solução. Algumas delas explicitam o desejo político de que houvesse uma efetiva integração dos descendentes de alemães à cultura nacional. Outras sugerem "nada menos do que a eliminação não só da Alemanha, mas de toda a raça" ${ }^{44}$.

O tema não se limita a esse romance; a ele voltam-se algumas outras obras ficcionais brasileiras que, na mesma década, dedicam-se a discutir questões semelhantes, associadas à imigração e, em menor número, à imigração alemã no Brasil. Dentre elas, destaco País de Ouro e Esmeralda (de José Antônio Nogueira, 1921) e o já citado Amar, Verbo Intransitivo (1927). Num recuo temporal maior, caberia acrescentar, é claro, Canaã (de Graça Aranha, 1902).

Os conflitos latentes com imigrantes e a expressão de ideias nacionalistas enquadram a ação do romance, que se encerra com a repercussão violenta, pela cidade de Porto Alegre, do episódio que culmina com a entrada do Brasil na Primeira Guerra Mundial. Enquanto Frida e Freitas se encontram secretamente, naquele que seria seu último encontro amoroso, noticia-se, pela cidade, que "submarinos alemães haviam torpedeado, já em águas de França, um navio brasileiro" ${ }^{45}$, episódio que provocaria a entrada do Brasil no conflito. O romance termina com a repercussão social desse episódio: quarteirões inteiros são incendiados, enquanto pessoas se manifestam pelas ruas, expressando opiniões diversas. Espectadores da ação, Frida e Freitas tentam escapar sem ser vistos de seu último encontro às escondidas, enquanto também tentam entender a dimensão e a consequência dos últimos acontecimentos.

Em linhas gerais, essa é a cena final do romance, que não entusiasmou o crítico Osório Duque-Estrada, como vimos anteriormente. A despeito de sua opinião sobre o desfecho - "Podia ser essa uma página empolgante, se fosse tratada por mão de mestre" - com a qual alguns podem concordar, o romance parece ser mais importante do que o crítico supôs. Dentre outros motivos, porque há poucas referências diretas à Primeira Guerra na prosa de ficção brasileira. O conflito aparece, nesse romance, representado por uma variedade de vozes e atitudes de personagens anônimos, que pensam em participar da guerra, ou que reagem ao que veem como o "perigo alemão" em terras brasileiras, ou ainda que, perplexos, imaginam quais os efeitos cotidianos dos atos de guerra praticados em domínios europeus. 
É verdade que a guerra propriamente dita não é o centro do romance. Não obstante, o capítulo final tem o mérito de construir uma imagem viva e plural dos efeitos dos eventos bélicos numa sociedade significativamente marcada pela presença alemã. Se a guerra não é o tema central do romance, é um elemento contextual pulsante, que vez por outra aparece textualmente, deixando perceber não o que se passa em outro continente, mas seus efeitos, os processos de mudança social em curso no país, especialmente aqueles que afetam os comportamentos e as expectativas a respeito dos papeis públicos e privados de uma geração.

\section{REFERÊNCIAS}

ANDRADE, Mário de. Amar, Verbo Intransitivo - Idilio. 1ª. ed. São Paulo, Casa Editora Antonio Tisi, 1927.

BANDEIRA, Manuel. Poesia Completa e Prosa. Rio de Janeiro, Nova Aguilar, 1996.

Bignotto, Cilza. Novas Perspectivas Sobre as Práticas Editoriais de Monteiro Lobato (1918-1925). Campinas, Unicamp, 2007. (Tese Doutorado).

CHARTIER, Roger. A Ordem dos Livros: Leitores, Autores e Bibliotecas na Europa Entre os Séculos XIV e XVIII. Trad. Mary Del Priori. Brasília, Editora Universidade de Brasília, 1999.

CoARAcy, Vivaldo. Frida Meyer. São Paulo, Companhia Gráfico-Editora Monteiro Lobato, 1924. DUQUE-EsTrADA, Osório. "Registro Literário”. Jornal do Brasil. 12.08.1925. Disponível em: http://memoria.bn.br/DocReader/DocReader.aspx?bib=030015_04\&PagFis=39816. Acesso em: 2 fev. 2016.

Hayet, Lucas Flores e AQuino, Vânia Campigotto. “Frida Meyer: a História da Busca de um Romance Desconhecido”. Anais Eletrônicos do II Congresso Internacional de História Regional. Passo Fundo, UPF Editora, 2013, vol. 1

Menucci, Sud. “Bibliographia”. O Estado de S. Paulo. 18.04.1925. Disponível em: <http://acervo.estadao.com.br/>. Acesso em: 5 fev. 2016.

MoraEs, Rubem Borba de. O Bibliófilo Aprendiz. 3ª ${ }^{\text {a }}$ ed. Rio de Janeiro/Brasília-DF, Casa da Palavra/Briquet de Lemos, 1998.

O Estado De S. Paulo. “Livros novos”. 28.10.1924. Disponível em: <http://acervo.estadao. com.br/>. Acesso em: 5 fev. 2016.

Terra, Eloy. As Ruas de Porto Alegre. Porto Alegre, AGE, 2001.

TinhorÃo, José Ramos. A Música Popular no Romance Brasileiro, vol. I: Séculos XVIII e XIX. São Paulo, Editora 34, 2000. 